\title{
Pengaruh Rasio Aktivitas, Solvabilitas dan Likuiditas terhadap Profitabilitas pada Perusahaan Pertambangan Batubara
}

\author{
Suwandi*, Jenny Thalia, Syakina, Munawarah \& Siti Aisyah \\ Program Studi Akuntansi, Fakultas Ekonomi, Universitas Prima Indonesia, Indonesia
}

Diterima: Maret 2019; Disetujui: Maret 2019; Dipublish: April 2019

*E-mail: suwandiwhittle@gmail.com

\begin{abstract}
Abstrak
Penelitian ini bertujuan untuk menguji dan menganalisis Pengaruh Rasio Aktivitas, Solvabilitas dan Likuiditas Terhadap Profitabilitas Perusahaan Pertambangan Batubara yang terdaftar di Bursa Efek Indonesia periode 2012-2016. Rasio aktivitas menggunakan Inventory Turnover, Working Capital Turnover, Total Asset Turnover dan Receivable Turnover sedangkan rasio solvabilitas menggunakan Debt to Equity Ratio dan rasio likuiditas menggunakan Current Ratio. Pendekatan penelitian adalah pendekatan kuantitatif asosiatif dengan sifat kausal. Populasi dalam penelitian ini adalah seluruh perusahaan pertambangan batubara yang terdaftar di BEI sebanyak 22 perusahaan. Terdapat 8 perusahaan yang dipilih dengan menggunakan metode purposive sampling. Dalam penelitian ini teknik analisis yang digunakan adalah analisis regresi linear berganda. Berdasarkan hasil uji hipotesis secara simultan, diperoleh pengaruh signifikan terhadap Profitabilitas, dengan hasil uji koefisien determinasi sebesar 34,5\%. Sedangkan berdasarkan hasil uji hipotesis secara parsial, Inventory Turnover, Debt to Equity Ratio, Working Capital Turnover, Current Ratio dan Receivable Turnover tidak berpengaruh signifikan terhadap profitabilitas dan Total Assets Turnover berpengaruh positif dan signifikan terhadap profitabilitas.
\end{abstract}

Kata Kunci: Aktivitas, Solvabilitas, Likuiditas, Profitabilitas

\begin{abstract}
Abstrak
This study aims to examine and analyze the Influence of Activity, Solvability and Liquidity Ratios towards the Profitability of Coal Mining Companies Listed on the Indonesia Stock Exchange (IDX) for the 20122016 period. The activity ratio variable uses Inventory Turnover, Working Capital Turnover, Total Asset Turnover and Receivable Turnover while the solvability ratio uses Debt to Equity Ratio and liquidity ratio using Current Ratio. The research approach used in this study is an associative quantitative approach with causal properties. The population in this study were 22 coal mining companies listed on the Indonesia Stock Exchange. There are 8 companies selected using the purposive sampling method. In this study the analysis technique used is multiple linear regression analysis. Based on the results of simultaneous hypothesis testing, obtained a significant effect on profitability, with the test results of the determination coefficient of 34.5\%. While based on the results of partial hypothesis testing, Inventory Turnover, Debt to Equity Ratio, Working Capital Turnover, Current Ratio and Receivable Turnover did not significantly affect profitability and Total Assets Turnover had a positive and significant effect on profitability.
\end{abstract}

Keywords: Activity, Solvability, Liquidity, Profitability.

How to Cite: Suwandi, Thalia, J. Syakina, Munawarah, Aisyah, S. (2019). Pengaruh Rasio Aktivitas, Solvabilitas Dan Likuiditas Terhadap Profitabilitas Pada Perusahaan Pertambangan Batubara. Journal of Education, Humaniora and Social Sciences (JEHSS). 1 (3): 181-187.

\section{PENDAHULUAN}

Seiring dengan meningkatnya pertumbuhan usaha, dibutuhkan pula manajemen perusahaan yang baik guna memastikan kelangsungan hidup perusahaan di era global ini. Profitabilitas menjadi kunci utama dalam melihat perkembangan dan pertumbuhan perusahaan, termasuk perusahaan pertambangan batubara. 
Profitabilitas dapat memberikan gambaran secara umum mengenai kemampuan dalam menghasilkan profit atau keuntungan. Dalam kenyataannya, tidak mudah bagi manajemen perusahaan untuk mempertahankan profitabilitas yang tinggi secara terus menerus mengingat sektor pertambangan batubara merupakan usaha yang padat modal dan membutuhkan investasi modal yang sangat banyak untuk mendukung kegiatan operasional sehingga dapat terjadi perputaran modal lambat jika tidak diterapkan manajemen yang baik.

Selain itu, banyak faktor lain yang sangat mempengaruhi profitabilitas perusahaan, salah satu nya adalah perputaran persediaan. Perusahaan memerlukan manajemen persediaan yang baik agar persediaan berada dalam jumlah yang optimum sehingga modal kerja yang dimiliki perusahaan dalam bentuk persediaan dapat diperkecil. Masalah yang sering muncul adalah ketika modal kerja terlalu banyak dalam bentuk persediaan sehingga perusahaan tidak mampu membiayai kegiatan operasional lainnya sehingga terjadi ketidakefektifan penggunaan modal kerja.

Dalam kasus seperti ini, perusahaan harus mengambil langkah untuk menambah modal kerja, salah satunya adalah melalui pinjaman. Dengan menambah modal melalui pinjaman diharapkan perusahaan mampu meningkatkan penjualan persediaan yang sebelumnya telah menumpuk, dan menghasilkan laba sehingga dapat menjalankan operasional perusahaan secara normal kembali.

Kemudian dengan bertambahnya utang perusahaan, masalah yang mungkin muncul berikutnya adalah ketidakmampuan perusahaan dalam membayar utang tersebut. Dalam hal ini, besar aset lancar perusahaan bahkan tidak mampu menutupi jumlah utang lancar yang dimiliki perusahaan.

Kondisi di atas sering terjadi pada perusahaan pertambangan batubara dikarenakan aktivitas operasi kegiatan pertambangan membutuhkan modal yang sangat besar, yang sebagian besar dialokasikan untuk aset tetap seperti mesin, kendaraan dan gedung yang memiliki harga yang sangat tinggi.

Masalahnya adalah perusahaan pertambangan batubara memiliki total aset yang sangat besar, namun terkadang tidak diiringi oleh hasil penjualan yang diinginkan. Hal ini kemudian menyebabkan total aset perusahaan tidak mampu menghasilkan penjualan yang sesuai dengan target perusahaan.

Adapun penyebab masalah di atas adalah dikarenakan penjualan yang terjadi secara kredit. Sehingga laba tidak dapat diterima secara langsung oleh perusahaan. Perusahaan harus menunggu piutang tersebut untuk dibayarkan dalam jangka waktu tertentu. Dan bahkan terkadang bisa saja piutang tersebut tak tertagih. Hal ini tentunya akan sangat mempengaruhi kemampuan perusahaan dalam menghasilkan laba.

\section{METODE PENELITIAN}

Pendekatan penelitian dalam penelitian ini adalah penelitian kuantitatif. Jenis penelitian dalam penelitian ini adalah penelitian asosiatif. Sifat penelitian dalam penelitian ini adalah kausal. Populasi dalam penelitian ini merupakan data-data keuangan yang berupa laporan keuangan tahunan dari perusahaan pertambangan batubara yang terdaftar di Bursa Efek Indonesia periode 2012-2016. Sedangkan teknik pengambilan sampel menggunakan teknik purposive sampling.

Perusahaan pertambangan batubara yang digunakan dalam penelitian ini berjumlah 8 (delapan) perusahaan dari total 22 (dua puluh dua) perusahaan pertambangan batubara yang terdaftar di Bursa Efek Indonesia periode 2012-2016 dengan total sampel yang menjadi observasi pada penelitian ini menjadi $8 \times 5$ tahun $=40$ sampel. 


\section{HASIL DAN PEMBAHASAN \\ Statistik Deskriptif}

Tabel 1

Statistik Desktriptif

\begin{tabular}{crrrrr}
\hline & N & Minimum & Maximum & \multicolumn{1}{c}{ Mean } & Std. Deviation \\
\hline ITO & 40 & 4.06119 & 41.55670 & 16.0538475 & 8.87753592 \\
DER & 40 & .16940 & 3.76867 & .7460075 & .58889964 \\
WCTO & 40 & -110.03284 & 45.88363 & .1577786 & 22.00068895 \\
CR & 40 & .49392 & 4.92374 & 1.9935848 & 1.00115046 \\
TATO & 40 & .38702 & 2.07032 & 1.1556545 & .38784339 \\
RTO & 40 & 3.44077 & 28.95257 & 11.3854731 & 5.19198749 \\
ROA & 40 & .00565 & .28972 & .0990805 & .06447170 \\
\hline Valid N (listwise) & 40 & \multicolumn{5}{l}{} \\
\hline
\end{tabular}

Hasil Uji Asumsi Klasik

\section{Uji Nomalitas}

Tabel 2

Hasil Uji Kolmogorov-Smirnov

\begin{tabular}{|c|c|c|}
\hline \multicolumn{3}{|c|}{ Unstandardized Residual } \\
\hline \multicolumn{2}{|c|}{$\mathrm{N}$} & 40 \\
\hline \multirow{2}{*}{$\begin{array}{c}\text { Normal } \\
\text { Parameters } \\
\text { a,b }\end{array}$} & Mean & .0000000 \\
\hline & Std. Deviation & .04799835 \\
\hline \multirow{3}{*}{$\begin{array}{c}\text { Most } \\
\text { Extreme } \\
\text { Differences }\end{array}$} & Absolute & .067 \\
\hline & Positive & .053 \\
\hline & Negative & -.067 \\
\hline \multicolumn{2}{|c|}{ Test Statistic } & .067 \\
\hline \multicolumn{2}{|c|}{ Asymp. Sig. (2-tailed) } & $.200^{\mathrm{c}, \mathrm{d}}$ \\
\hline
\end{tabular}

Sumber : Output SPSS 22.00 (2018)

Hasil uji Kolmogorov-Smirnov pada tabel 1 menunjukkan bahwa nilai Kolmogorov-Smirnov sebesar 0,067 dengan nilai Asymp. Sig. (2-tailed) adalah 0,200>0,05 yang merupakan kriteria uji statistik Kolmogorov-Smirnov sehingga dapat disimpulkan bahwa data berdistribusi normal.

\section{Uji Multikolinearitas}

Tabel 2

Hasil Uji Multikolinearitas

\begin{tabular}{|c|c|c|c|}
\hline \multirow{2}{*}{\multicolumn{2}{|c|}{ Model }} & \multicolumn{2}{|c|}{ Collinearity Statistics } \\
\hline & & Tolerance & VIF \\
\hline \multirow[t]{7}{*}{1} & (Constant) & & \\
\hline & ITO & .858 & 1.166 \\
\hline & DER & .741 & 1.350 \\
\hline & WCTO & .839 & 1.192 \\
\hline & CR & .726 & 1.378 \\
\hline & TATO & .754 & 1.327 \\
\hline & RTO & .767 & 1.304 \\
\hline
\end{tabular}

Sumber : Output SPSS 22.00 (2018)

Berdasarkan hasil uji multikolinearitas pada tabel 2 dapat dilihat bahwa semua variabel memiliki VIF yang lebih kecil dari 10 dan nilai tolerance yang lebih besar dari 0,1. Dengan 
demikian dapat dinyatakan bahwa model persamaan regresi dalam penelitian ini tidak mengalami masalah multikolinearitas.

\section{Uji Autokorelasi}

\section{Tabel 3}

Hasil Uji Autokorelasi

\begin{tabular}{ccc}
\multicolumn{3}{c}{ Hasil Uji Autokorelasi } \\
\hline $\begin{array}{c}\text { Std. Error of the } \\
\text { Estimate }\end{array}$ & Durbin-Watson \\
Model &, 05217971 & 2.024 \\
\hline 1 & \multicolumn{3}{c}{ Sumber : Output SPSS 22.00 (2018) }
\end{tabular}

Dari tabel 3 di atas menunjukkan bahwa diperoleh nilai probabilitas Durbin Watson sebesar 2,024. Pada penelitian ini, $\mathrm{k}$ adalah jumlah banyaknya variabel bebas maka $\mathrm{k}=6, \mathrm{n}$ adalah banyaknya observasi maka $\mathrm{n}=40$. Nilai $\mathrm{dl}=1,1754$ dan nilai $\mathrm{du}=1,8538$; dan $4-\mathrm{du}=$ 2,1462. Dengan melihat kriteria pada pedoman Durbin-Watson maka nilai du $<\mathrm{dw}<4$-du atau $1,8538<2,024<2,1462$ maka hasil uji autokorelasi menunjukkan bahwa pada model tersebut tidak terjadi autokorelasi positif maupun negatif dengan keputusan tidak ditolak.

\section{Uji Heteroskedastisitas}

Tabel4 Hasil Uji Park

\begin{tabular}{ccc}
\hline & Model & \multicolumn{1}{c}{ Sig. } \\
\hline 1 & (Constant) & .419 \\
& LN_ITO & .959 \\
& LN_DER & .186 \\
& LN_WCTO & .901 \\
& LN_CR & .877 \\
& LN_TATO & .846 \\
LN_RTO & .056 \\
\hline
\end{tabular}

Sumber : Output SPSS 22.00 (2018)

Berdasarkan hasil uji Park pada tabel 5, nilai signifikan semua variabel independen lebih besar dari 0,05 yang artinya model regresi tidak mengalami masalah heterokedastisitas.

Tabel 5

Hasil Persamaan Regresi Linier Berganda

\begin{tabular}{|c|c|c|c|c|}
\hline & \multirow[b]{2}{*}{ Model } & \multicolumn{2}{|c|}{$\begin{array}{l}\text { Unstandardized } \\
\text { Coefficients }\end{array}$} & \\
\hline & & B & Std. Error & \\
\hline \multirow[t]{7}{*}{1} & (Constant) & .014 & .053 & \\
\hline & ITO & -.002 & .001 & \\
\hline & DER & -.014 & .016 & \\
\hline & WCTO & .000 & .000 & \\
\hline & CR & .017 & .010 & \\
\hline & ТАТО & .088 & .025 & \\
\hline & RTO & -.001 & .002 & $\begin{array}{l}\text { Sumber : Output SPSS } 22.00 \\
(2018)\end{array}$ \\
\hline
\end{tabular}

Persamaan regresi yang terbentuk berdasarkan hasil olah data adalah sebagai berikut : $\mathrm{Y}=$ $0,14-0,002 X_{1}-0,014 X_{2}-0,000 X_{3}+0,17 X_{4}+0,88 X_{5}-0,001 X_{6}+e$

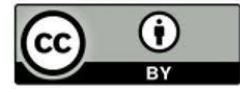




\section{Koefisien Determinasi Hipotesis}

\begin{tabular}{rlrrr}
\multicolumn{5}{c}{ Tabel 6 } \\
Model & R & R Square & Adjusted R Square & Std. Error of the Estimate \\
\hline 1 & $.668^{a}$ & .446 & .345 & .05217971 \\
\hline
\end{tabular}

Sumber : Output SPSS 22.00 (2018)

Berdasarkan tabel 6, nilai Adjusted $\mathrm{R}^{2}$ adalah 0,345. Dengan demikian dapat disimpulkan bahwa kemampuan variabel independen dalam menerangkan variasi variabel dependenadalah sebesar 34,5\%, sedangkan sisanya sebesar 65,5 \% dijelaskan oleh variabel-variabel lain diluar model penelitian ini.

\section{Pengujian Secara Simultan (Uji F)}

Tabel 7 Hasil Uji F

\begin{tabular}{llrll}
\hline & Model & df & F & Sig. \\
\hline 1 & Regression & 6 & 4.423 & $.002^{\mathrm{b}}$ \\
& Residual & 33 & & \\
Total & 39 & & \\
\hline
\end{tabular}

Sumber : Output SPSS 22.00 (2018)

Berdasarkan hasil uji F pada tabel 7, maka variabel inventory turnover, debt to equity ratio, working capital turnover, current ratio, total asset turnover dan receivable turnover secara simultan berpengaruh signifikan terhadap profitabilitas pada perusahaan pertambangan batubara.

\section{Pengujian Secara Parsial (Uji t)}

\begin{tabular}{llll}
\multicolumn{3}{c}{$\begin{array}{c}\text { Tabel 9 } \\
\text { Hasil Uji t }\end{array}$} \\
\hline Model & $\mathrm{T}$ & Sig. \\
\hline $1 \quad$ (Constant) & .267 & .791 \\
& ITO & -1.486 & .147 \\
DER & -.875 & .388 \\
WCTO & .584 & .563 \\
CR & 1.746 & .090 \\
TATO & 3.560 & .001 \\
RTO & -.779 & .442 \\
\hline \multicolumn{3}{c}{ Sumber : Output SPSS 22.00 (2018) }
\end{tabular}

Berdasarkan hasil uji $\mathrm{t}$ pada tabel 9, dapat dijelaskan sebagai berikut : Inventory turnoversecara parsial tidak berpengaruh signifikan terhadap profitabilitas pada perusahaan pertambangan batubara; Debt to equity ratiosecara parsial tidak berpengaruh signifikan terhadap profitabilitas pada perusahaan pertambangan batubara; Working capital turnoversecara parsial tidak berpengaruh signifikan terhadap profitabilitas pada perusahaan pertambangan batubara; Current ratiosecara parsial tidak berpengaruh signifikan terhadap profitabilitas pada perusahaan pertambangan batubara; Total asset turnoversecara parsial berpengaruh positif dan signifikan terhadap profitabilitas pada perusahaan pertambangan batubara; Receivable turnover secara parsial tidak berpengaruh signifikan terhadap profitabilitas pada perusahaan pertambangan batubara.

Berdasarkan hasil analisis regresi linier berganda, hanya 2 variabel independen (CR dan TATO) yang memiliki pengaruh positif dengan variabel dependen. Sedangkan 4 variabel independen lainnya (ITO, DER, WCTO dan RTO) memiliki pengaruh negatif dengan variabel dependen. Hal ini dikarenakan aset lancar dan total aset merupakan faktor produksi yang mutlak 
diperlukan oleh perusahaan pertambangan batubara dalam menjalankan kegiatan operasionalnya. Kegiatan operasional yang lancar tentunya akan menghasilkan keuntungan sehingga meningkatkan profitabilitas perusahaan.

Berdasarkan hasil koefisien determinasi hipotesis, diperoleh bahwa kemampuan variabel independen dalam menjelaskan variasi variabel dependen adalah sebesar 34,5\% sedangkan sisanya sebesar $65,5 \%$ dijelaskan oleh variabel-variabel lain diluar model penelitian ini.

Berdasarkan hasil pengujian secara simultan (uji $t$ ), semua variabel independen berpengaruh signifikan terhadap varibel dependen. Hal ini dikarenakan semua variabel independen memiliki kontribusi tertentu terhadap kemampuan perusahaan dalam menghasilkan laba, meskipun masing-masing nilai kontribusi tersebut tidak sama jumlahnya. Sebagai contoh variabel CR dan TATO memiliki nilai kontribusi lebih besar dibandingkan variabel independen lainnya, karena perusahaan pertambangan batubara wajib memenuhi kebutuhan aset, terutama aset tetap seperti mesin, kendaraan, dan tanah untuk menjalankan kegiatan operasionalnya. Sehingga jika dilakukan uji secara simultan, besar nilai kontribusi CR dan TATO dapat menutupi nilai kontribusi variabel dependen lainnya yang tidak tertalu besar,

Berdasarkan hasil pengujian secara parsial (uji t), diperoleh bahwa dari semua variabel independen hanya TATO yang memiliki pengaruh signifikan dan positif terhadap variabel dependen. Hal ini menggambarkan bahwa total aset menjadi kunci utama perusahaan pertambangan batubara dalam menghasilkan keuntungan karena tanpa aset khususnya aset tetap, mustahil perusahaan pertambangan batubara dapat menjalankan kegiatan operasionalnya.

\section{SIMPULAN}

Semua variabel independen memiliki nilai kontribusi tertentu terhadap kemampuan perusahaan menghasilkan keuntungan. Namun nilai kontribusi masing-masing variabel tidaklah sama. Berdasarkan berbagai hasil uji, diperoleh bahwa variabel yang berhubungan dengan aset memiliki nilai kontribusi lebih tinggi daripada variabel independen lain yang tidak. Aset menjadi kunci utama perusahaan pertambangan batubara dalam menghasilkan keuntungan. Dalam melakukan kegiatan operasionalnya, perusahaan pertambangan batubara memerlukan mesin, kendaraan, dan lahan tambang yang semuanya merupakan bagian dari aset, khususnya aset tetap. Meskipun perusahaan memiliki persediaan yang cukup, tingkat pinjaman yang wajar, modal kerja yang cukup dan bahkan piutang yang tertagih dalam keadaan baik, hal ini tidak dapat membantu perusahaan menghasilkan batubara, jika tidak adanya aset tetap seperti mesin, kendaraan dan lahan tambang

\section{DAFTAR PUSTAKA}

Ainiyah, Q. (2016). Pengaruh Perputaran Piutang, Perputaran Persediaan dan Debt to Equity Ratio Terhadap Profitabilitas.Jurnal Ilmu dan Riset Manajemen Vol. 5 (1).

Anto, J. (2013). Pengaruh Current Ratio, Debt to Equity Ratio, Receivable Turnover, Sales Growth Terhadap Return on Asset Pada Semua Perusahaan Manufaktur Yang Terdaftar Di BEI (Periode 2008-2012). Jurnal Ilmu dan Riset Manajemen Vol. 6 (3).

Ayu, P.M. et.al. (2016). Pengaruh Current Ratio dan Debt to Equity Ratio Terhadap Return on Assets.Jurnal Widyakala Vol. 3.

Budiang, F.T. et.al. (2017). Pengaruh Perputaran Total Aset, Perputaran Piutang dan Perputaran Persediaan Terhadap ROA Pada Perusahaan Sub Sektor Perdagangan Eceran Yang Terdaftar di BEI.Jurnal EMBA Vol. 5 (2).

Fahmi, I. (2014). Pengantar Manajemen Keuangan Teori dan Soal Jawab. Cetakan Ketiga. Bandung: Alfabeta.

Harahap, S.S. (2015). Analisis Kritis Atas Laporan Keuangan. Cetakan Kedua Belas. Jakarta: PT RajaGrafindo Persada.

Hery. (2015). Pengantar Akuntansi: Comprehensive Editon Lengkap Dengan Kumpulan Soal dan Solusinya. Jakarta: PT Grasindo.

Kasmir. (2012). Analisis Laporan Keuangan. Cetakan Kelima. Jakarta: PT RajaGrafindo Persada.

Sudana, I. M. (2011). Manajemen Keuangan Perusahaan Teori \& Praktik. Surabaya: Erlangga. 
Supardi, H.et.at. (2016). Pengaruh Current Ratio, Debt to Asset Ratio, Total Asset Turnover dan Inflasi Terhadap Return on Asset. Jurnal Ilmiah Akuntansi Fakultas Ekonomi Vol. 2 (2).

Sutrisno. (2013). Manajemen Keuangan Teori Konsep dan Aplikasi. Cetakan Kesembilan. Yogyakarta: Ekonisia.

Taufiqurrohman, C. et.al. (2017). Pengaruh Working Capital Turnover dan Current Ratio Terhadap Return on Asset Pada Perusahaan Farmasi Yang Terdaftar di BEI Tahun 2013-2016.Jurnal Kebangsaan Vol. 6 (12). 